\title{
Effect of ultrasound use on the pathological outcomes in temporal artery biopsy
}

\section{Temporal arter biyopsilerinde ultrason kullanımının patolojik sonuçlar üzerine etkisi}

\author{
Fikret SAHINTURK*回, Erkin SONMEZ1' , Coskun ARAZ²
}

'Baskent University School of Medicine, Department of Neurosurgery, Ankara/TURKEY

${ }^{2}$ Baskent University School of Medicine, Department of Anesthesiology, Ankara/TURKEY

\begin{abstract}
Aim: This study aimed to determine whether there is a significant difference between the results of a standard biopsy and Doppler ultrasonography-guided biopsy of the temporal artery, which showed low preoperative pulse pressure.

Material and Methods: Data from 21 patients, who received preliminary diagnosis of temporal arteritis at the neurology clinic were retrospectively investigated. Patients were divided into two groups depending on the method with Doppler ultrasonography and without ultrasonography.
\end{abstract}

Results: Results from a total of 21 patients were evaluated. The first group consisted of 11 patients who underwent standard temporal artery biopsy, while the second group consisted of 10 patients who underwent ultrasonography-guided biopsy. Six patients in the group without the ultrasonography guidance showed insignificant results. Furthermore, the samples were insufficient in four of these six patients. In contrast, four patients from the Doppler ultrasonography-guided group were diagnosed with arteritis, in addition to the fact that an insufficient biopsy sample was not encountered in these patients.

Statistical analysis showed that there was no significant difference between the pathology results of the two groups.

Conclusion: Although we failed to find a significant difference between the groups, we believe that the Doppler ultrasonographyguided biopsy should be used as a supportive tool rather than diagnostic tool per se, as the Doppler ultrasonography-guided group did not provide insufficient biopsy samples in the pathology results as opposed to the standard group.

Keywords: Giant cell arteritis; ultrasonography; pathology 


\section{öz}

Amaç: Bu çalışmanın amacı, cerrahi işlem öncesinde nabız basıncı düşük olan temporal arterin, dopler ultrasonografi ile tespit edilen bölgeden alınan biyopsi ile standart biyopsilerin sonuçları arasında anlamlı farklılığın olup olmadığını değerlendirmektir.

Gereç ve Yöntemler: 2013-2019 yılları arasında merkezimizde nöroloji kliniğinde temporal arterit ön tanısı ile değerlendirilen ve biyopsi uygulanması için beyin ve sinir cerrahisi bölümüne konsülte edilen toplam 21 hastanın verileri retrospektif olarak incelendi. Hastaların medikal kayıtlarından toplanan veriler; hastaların demografik özellikleri (yaş, cinsiyet), alınan biyopsinin uzunluğu, görme kaybı varlığı, baş ağrısı varlığı, biyopsi öncesi eritrosit sedimantasyon hızı ile c-reaktif protein düzeyi ve cerrahide dopler ultrasongrafi kullanım durumu kaydedildi.

Hastalar, dopler ultrasonografi kullanılan ve kullanılmayan olarak iki gruba ayrıldı.

Biyopsi öncesi dopler ultrasonografi kullanımında deneyimli, anesteziyoloji uzmanı tarafından inflamasyona bağlı kanlanmanın az olduğu temporal arter trasesi ve dalları cilt üzerinden noktasal işaretleme yapılarak tespit edildi.

Standart biyopsi uygulamasında temporal arterin anatomik lokalizasyonuna göre cilt insizyonu yapılarak, ultrason eşliğindeki biyopside ise belirlenen traseye uygun olacak şekilde yapılan cilt insizyonu ile temporal artere ulaşıldı. Arter dokusundan yaklaşık $2 \mathrm{~cm}$ olacak şekilde biyopsi alındı.

Bulgular: Toplam 21 hastanın sonuçları incelendi. Hastalar işlem sırasında dopler ultrasonografi kullanımına göre 2 gruba ayrıldı. İlk grup 11 hastadan oluşan standart temporal arter biyopsi uygulanan grup, ikinci grup ise toplam 10 hastadan oluşan ultrason eşliğinde biyopsi yapılan grup olarak belirlendi. Hastaların ortalama yaşları 69 (39y-90y) olarak bulundu. Ultrason eşliğinde alınan doku örneklerinin ortalama uzunluğu 1,96 $\pm 0.46 \mathrm{~cm}$, standart cerrahi uygulanan biyopsi örneklerinin ortalama uzunluğunun $1,70 \pm 1.07 \mathrm{~cm}$ olduğu tespit edildi. Yapılan istatiksel analizde doppler kullanımının alınan örnek uzunluğunda anlamlı bir fark oluşturmadığı tespit edildi. ( $p=0.215$ ) Biyopsi sırasında ultrason uygulanmayan toplam 11 hastanın altısında patoloji sonucunun anlamlı olmadığı ve bu altı hastadan dördünde patoloji sonucu yetersiz örnek olarak raporladı. Buna karşılık dopler ultrasonografi eşliğinde biyopsi alınan 10 hastanın dördüne arterit tanısı kondu ve yetersiz örnek sonucu ile karşılaşılmadı.

Sonuç: Çalışmamızdaki iki gurup arasında anlamlı fark olmasa da doppler yapılan gruptaki patoloji sonuçlarında yetersiz örnek sonucu ile karşılaşılmamış olması, dopler eşliğinde yapılan biyopsinin tanı koydurucu değil destekleyici uygulama olarak kullanılması kanaatindeyiz.

Anahtar kelimeler: Büyük hücre arteriti; ultrasonografi; patoloji

\section{Introduction}

Giant cell arteritis (GCA) is primary systemic vasculitis of unknown cause that generally affects large- and medium-sized arteries. The temporal artery is reported to be the most frequently affected [1]. GCA generally develops after the age of 60 years, and its frequency increases with age. Women have an almost threefold increased risk of developing GCA compared to men [2]. Inflammation on the artery wall leads to occlusion of the artery lumen and ischemic tissue that causes clinical symptoms. The temporal arteries, optic nerve, masseter muscle, and posterior circulation of the central nervous system are susceptible to GCA [3]. Headache and pain on the temporal artery trace are among the common symptoms reported by patients [4]. However, this disease may affect various arteries and cause a wide variety of nonpathognomonic symptoms. Symptoms of GCA can be divided into four groups: symptoms of cranial arteritis, symptoms of extracranial arteritis, systemic symptoms, and polymyalgia rheumatic [5]. The most severe complication of GCA is irreversible vision loss due to late diagnosis [6].

Transmural inflammation in temporal artery biopsy is the gold standard for GCA diagnosis [7,8]. However, a negative result from temporal artery biopsy is inadequate to rule out GCA. According to the previous studies, $44 \%$ of patients with GCA had negative biopsy results. Such negative biopsy results were attributed to the discontinuity of inflammatory changes in the temporal artery and insufficient length of the biopsy sample [9-11].

This study aimed to determine whether there is a significant difference between the results of standard biopsy and Doppler ultrasonography-guided biopsy of the temporal artery, which showed low preoperative pulse pressure. 


\section{Material and Methods}

Data from 21 patients, who received preliminary diagnosis of temporal arteritis at the neurology clinic of our center and were transferred to the neurosurgery department for biopsy between 2013 and 2019, were retrospectively investigated.
Data collected from the medical records of the patients included demographics (age, sex), length of the biopsy sample, presence of vision loss, headache, prebiopsy erythrocyte sedimentation rate, and C-reactive protein (CRP) levels and biopsy method (with or without Doppler ultrasonography) (Table 1).

\begin{tabular}{|c|c|c|c|c|c|c|c|c|}
\hline Patient Number & Age & Sex & Sample Length $(\mathrm{cm})$ & Doppler & Visual loss & Headache & $\mathrm{ESR}$ (mm/saat) & $\mathrm{CRP}(\mathrm{mg} / \mathrm{L})$ \\
\hline 1 & 87 & $\mathrm{~F}$ & 2 & with & + & - & 78 & 71,7 \\
\hline 2 & 87 & $\mathrm{~F}$ & 0,5 & without & + & + & 106 & 47,9 \\
\hline 3 & 53 & $\mathrm{~F}$ & 2 & with & + & - & 13 & 4,5 \\
\hline 4 & 53 & M & 0,6 & without & + & - & 31 & 10,2 \\
\hline 5 & 62 & $\mathrm{~F}$ & 2,1 & with & + & + & 25 & 7,3 \\
\hline 6 & 53 & M & 2,5 & with & + & - & 91 & 16 \\
\hline 7 & 78 & $\mathrm{~F}$ & 4,2 & without & - & + & 60 & 51,7 \\
\hline 8 & 59 & $\mathrm{~F}$ & 1,2 & without & - & + & 93 & 41,3 \\
\hline 9 & 90 & $\mathrm{~F}$ & 2,5 & without & + & + & 108 & 49 \\
\hline 10 & 64 & $\mathrm{~F}$ & 1,4 & without & - & + & 8 & 1 \\
\hline 11 & 68 & M & 2,5 & without & + & + & 71 & 43,1 \\
\hline 12 & 59 & $M$ & 0,9 & without & + & - & 9 & 5,14 \\
\hline 13 & 80 & $M$ & 2,6 & with & + & - & 25 & 13,4 \\
\hline 14 & 83 & $\mathrm{~F}$ & 1,2 & without & - & + & 19 & 27,7 \\
\hline 15 & 83 & M & 2 & without & + & - & 54 & 18,35 \\
\hline 16 & 78 & $M$ & 1,6 & with & - & + & 32 & 6,83 \\
\hline 17 & 39 & $\mathrm{~F}$ & 1,7 & without & + & - & 23 & 20,6 \\
\hline 18 & 72 & $\mathrm{~F}$ & 2,2 & with & + & - & 27 & 2 \\
\hline 19 & 68 & $\mathrm{~F}$ & 1 & with & - & + & 23 & 8,2 \\
\hline 20 & 58 & $\mathrm{~F}$ & 1,6 & with & + & - & 8 & 2,1 \\
\hline 21 & 77 & M & 2 & with & + & - & 20 & 8,2 \\
\hline
\end{tabular}

The patients were divided into two groups depending on the method: with Doppler ultrasonography and without Doppler ultrasonography. The upper limits for erythrocyte sedimentation rate (ESR) and CRP level were indicated as 25 $\mathrm{mm} / \mathrm{h}$ and $5 \mathrm{mg} / \mathrm{L}$, respectively.

Before the biopsy, temporal artery trace and branches that had inflammation-related poor circulation were identified by skin marking by an anesthesiologist experienced in Doppler ultrasonography (Figure1-2).

The surgical procedures were performed under local anesthesia after obtaining written informed consent from all patients who underwent biopsy. A skin incision was created according to the anatomical location of the temporal artery during standard biopsy, whereas the temporal artery was accessed by creating a skin incision according to the identified trace in the ultrasonography-guided biopsy. Approximately $2 \mathrm{~cm}$ of artery tissue was obtained in the biopsy. Then, the biopsy samples were placed in $10 \%$ formaldehyde solution for pathological examination.

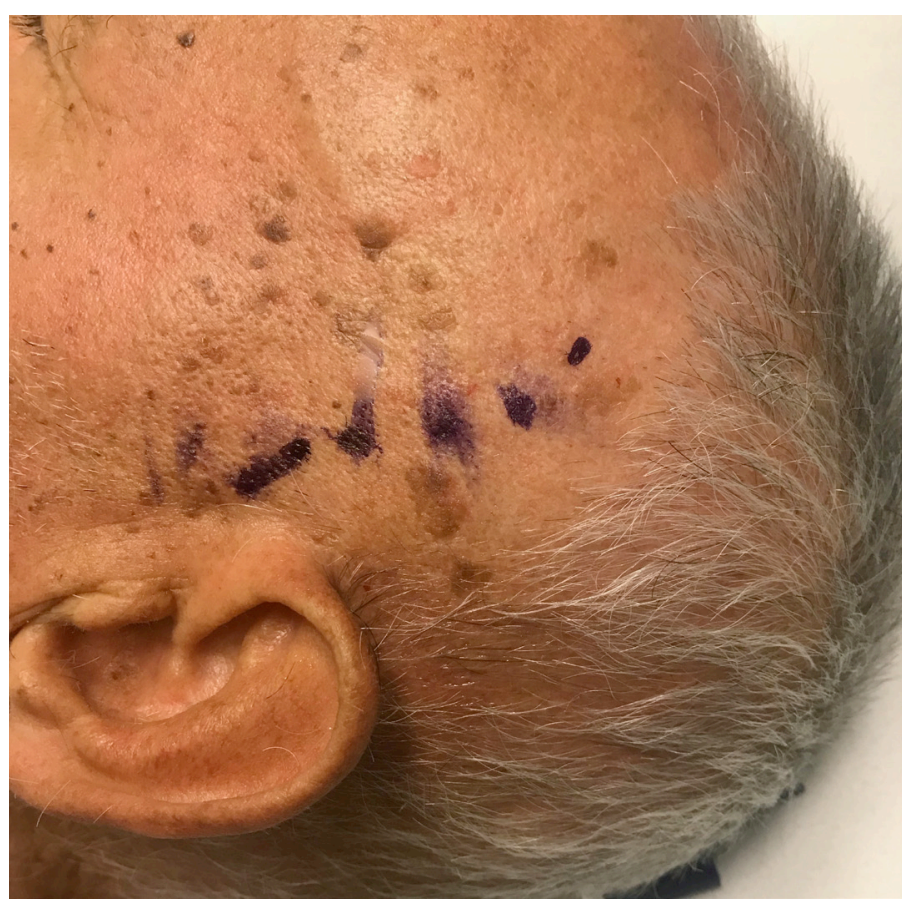

Fig 1: Skin Marking 


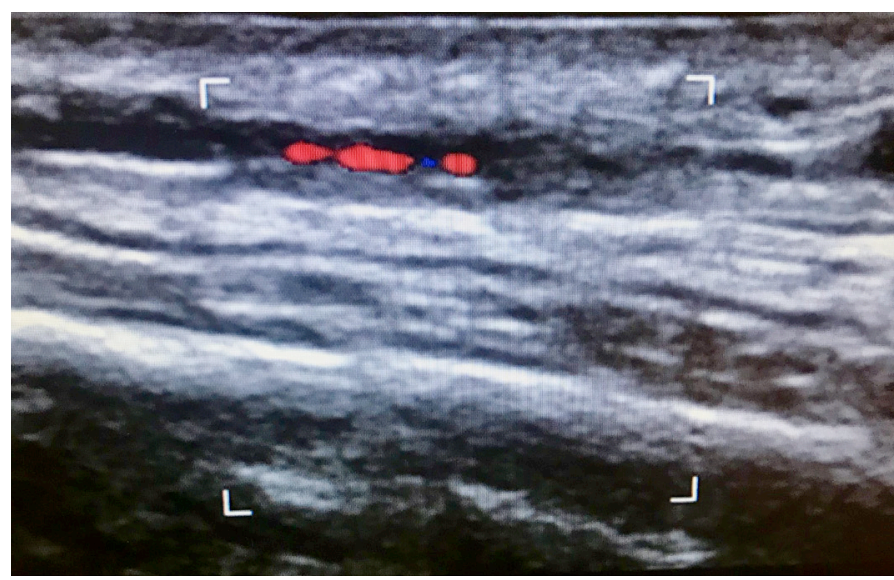

Fig 2: Temporal Artery Trace in Doppler Ultrasonography

Statistical analyses were conducted using SPSS 25.0. The statistical significance level was set at a P-value $<0.05$. MannWhitney $U$ test was used to compare continuous demographic data of two independent groups, depending on the number of subjects and without performing normality tests. The results were reported in median values and ranges. Chi-square or Fisher's exact test was used to evaluate the homogeneity of categorical variable distribution. The descriptive statistics were reported in frequency distribution and percentage values. Sensitivity, selectivity, positive and negative predictive values, and positive and negative likelihood ratios of Doppler ultrasonography and pathology results were calculated. The results were specified with the relevant confidence intervals (95\% confidence interval upper and lower limits).

Before the procedure, consent forms were obtained from the patients. Ethics committee application approval was not received, as the study retrospectively analyzed the data before 2020 .

\section{Results}

In the present study, the results of 21 patients who underwent temporal artery biopsy at our clinic between 2013 and 2019 were evaluated. The patients were divided into two groups depending on the use of Doppler ultrasonography. The first group consisted of 11 patients who underwent standard temporal artery biopsy, while the second group consisted of 10 patients who underwent ultrasonography-guided biopsy. The mean patient age was 69 years (range, 39-90). The female/male ratio was 1.6. Nonparametric Mann-Whitney $U$ test was used to compare the two groups in terms of continuous variables, such as age, sample length, ESR, and CRP level by taking into account the number of subjects. The mean length of the tissue samples of ultrasonography-guided biopsy and standard biopsy were $1.96 \pm 0.46 \mathrm{~cm}$, and $1.70 \pm 1.07 \mathrm{~cm}$, respectively (Table 1). Statistical analysis showed that use of Doppler ultrasonography did not lead to a significant difference in sample length ( $p=$ 0.215). A comparison of the preoperative biochemistry results showed that there was no statistically significant relationship between ESR and CRP level ( $p=0.359 ; p=0.057$ ).

Six patients (54\%) in the group without the ultrasonography guidance showed insignificant results. Furthermore, the samples were insufficient in four of these six patients. In contrast, four patients (40\%) from the Doppler ultrasonography-guided group were diagnosed with arteritis, in addition to the fact that an insufficient biopsy sample was not encountered in these patients.

Statistical analysis showed that there was no significant difference between the two groups in terms of pathology results. Analyses revealed that the sensitivity of Doppler ultrasonography was $30 \%$. Although we failed to find a significant difference between the groups, the Doppler group did not provide insufficient biopsy samples according to the pathology results.

\section{Discussion}

Temporal artery biopsy is considered the gold standard that supports GCA diagnosis. However, it was reported that nearly $13 \%-44 \%$ of patients who are clinically suspected to have GCA might have negative biopsy results due to the segmental structure of the inflammatory lesions within the temporal artery [12]. This study primarily aimed to investigate the possible difference between the results of standard temporal artery biopsy and biopsy performed on a poorly circulated area due to inflammation-related occlusion of the artery lumen in the temporal artery. Therefore, the patients who underwent biopsy on suspicion of a temporal arteritis were retrospectively evaluated.

In the present study, 14 (66\%) of the 21 patients had negative biopsy results. Besides, six (60\%) of the 10 patients who underwent Doppler ultrasonography-guided biopsy had negative biopsy results. Misdiagnosed and late-treated patients are at higher risks. The reason for this is that permanent vision loss is observed nearly in 19\% of patients with GCA before initiation of the glucocorticoid therapy [13]. Therefore, techniques that can increase the sensitivity of temporal artery biopsy are needed [14]. It was reported in previous studies that the presence of a halo sign in Doppler ultrasonography is a specific finding for temporal arteritis [15.16]. Ball et al. showed in a meta-analysis performed on 17 studies and 998 patients that comparison of the presence of halo sign in Doppler ultrasonography and temporal artery biopsies revealed that the sensitivity of the halo sign was $75 \%$, while the specificity was $83 \%$. The authors recommend biopsy as the first-choice diagnostic method in patients who have negative ultrasonographic results [17]. 
Germano et al. [14] compared ultrasonography-guided biopsies in 112 patients and reported that $49 \%-85 \%$ of patients with GCA are have positive temporal artery biopsy results. These variations probably stem from the different clinical and histological definitions of GCA and technical differences in the collection and processing of biopsy samples. The length of the biopsy sample should be at least $0.5-1 \mathrm{~cm}$ for diagnostic efficiency. In our study, the mean length of the biopsy samples was $1.82 \pm 0.83 \mathrm{~cm}$, which is considered a sufficient tissue length for diagnosis in the literature. The contribution of Doppler ultrasonography in guiding the temporal artery biopsy is still controversial in relevant studies.

The limitation of this study and other publications in the literature is glucocorticoid therapy. Hauenstein showed that the sensitivity of biopsy was rapidly decreased with glucocorticoid therapy [18]. Therefore, the limitation of the present study can be the glucocorticoid therapy duration before the biopsy. Hence, we believe that the results would be significant for a biopsy procedure performed before glucocorticoid therapy.

\section{Conclusion}

Therefore, we believe that Doppler ultrasonographyguided biopsy should be used as a supportive tool rather than diagnostic tool per se, as we failed to find a significant difference between the groups. The Doppler group did not provide sufficient biopsy samples in the pathology results as opposed to the standard group.

\section{Declaration of conflict of interest}

The authors received no financial support for the research and/or authorship of this article. There is no conflict of interest

\section{References}

1. Turesson C, Börjesson O, Larsson K, Mohammad AJ, Knight A. Swedish Society of Rheumatology 2018 guidelines for investigation, treatment, and follow-up of giant cell arteritis. Scandinavian Journal of Rheumatology 2019; 48: 1-7.

2. Mohammad AJ, Nilsson J- $\AA$, Jacobsson LT, Merkel PA, Turesson C. Incidence and mortality rates of biopsy-proven giant cell arteritis in southern Sweden. Annals of the Rheumatic Diseases 2015; 74: 993-7.

3. Wojczal J, Kozera G, Luchowski P, Neubauer-Geryk J. Advantages in diagnosis of giant cell arteritis by ultrasound. Advances in Dermatology and Allergology/Post囚py Dermatologii i Alergologii 2019; 36: 25.

4. Huston KA, Hunder GG, Lie JT, Kennedy RH, Elveback LR. Temporal arteritis: a 25-year epidemiologic, clinical, and pathologic study. Annals of Internal Medicine 1978; 88: 162-7.
5. Nesher G. The diagnosis and classification of giant cell arteritis. Journal of Autoimmunity 2014; 48: 73-5.

6. Font C, Cid MC, Coll-Vinent B, López-Soto A, Grau JM. Clinical features in patients with permanent visual loss due to biopsy-proven giant cell arteritis. British Journal of Rheumatology 1997 ;36: 251-4.

7. Salvarani C, Cantini F, Boiardi L, Hunder GG. Polymyalgia rheumatica and giant-cell arteritis. The New England Journal of Medicine 2002; 347: 261-71.

8. Salvarani C, Pipitone N, Versari A, Hunder GG. Clinical features of polymyalgia rheumatica and giant cell arteritis. Nature Reviews Rheumatology 2012; 8: 509-21.

9. Hall S, Lie JT, Kurland LT, Persellin S, O'Brien PC, Hunder GG. The therapeutic impact of temporal artery biopsy. The Lancet 1983; 322: 1217-20.

10. Allsop CJ, Gallagher PJ. Temporal artery biopsy in giant-cell arteritis. A reappraisal. The American Journal of Surgical Pathology 1981; 5: 317-23.

11. Poller $D$, Van Wyk $Q$, Jeffrey $M$. The importance of skip lesions in temporal arteritis. Journal of Clinical Pathology 2000; 53: 137-9.

12. Gonzalez-Gay MA, Garcia-Porrua C, Llorca J, Gonzalez-Louzao C, Rodriguez-Ledo P. Biopsy-negative giant cell arteritis: clinical spectrum and predictive factors for positive temporal artery biopsy. Seminars in arthritis and rheumatism Elsevier 2001; 30: 249-56.

13. Salvarani $C$, Cimino $L$, Macchioni $P$ et al. Risk factors for visual loss in an Italian population-based cohort of patients with giant cell arteritis. Arthritis Care \& Research: Official Journal of the American College of Rheumatology 2005; 53: 293-7.

14. Germanò G, Muratore F, Cimino L et al. Is colour duplex sonography-guided temporal artery biopsy useful in the diagnosis of giant cell arteritis? A randomized study. Rheumatology 2014; 54: 400-4.

15. Schmidt WA, Kraft HE, Vorpahl K, Völker L, Gromnica-lhle EJ. Color duplex ultrasonography in the diagnosis of temporal arteritis. New England Journal of Medicine 1997; 337: 1336-42.

16. Salvarani C, Silingardi M, Ghirarduzzi A et al. Is duplex ultrasonography useful for the diagnosis of giant-cell arteritis? Annals of Internal Medicine 2002; 137: 232-8.

17. Ball EL, Walsh SR, Tang TY, Gohil R, Clarke JM. Role of ultrasonography in the diagnosis of temporal arteritis. British Journal of Surgery 2010; 97: 1765-71.

18. Hauenstein C, Reinhard M, Geiger J et al. Effects of early corticosteroid treatment on magnetic resonance imaging and ultrasonography findings in giant cell arteritis. Rheumatology 2012; 51: 1999-2003. 